\title{
Thermal Performance Testing and Promotion of Solar Cooker Under Djiboutian Climate
}

\author{
Abdoulkader I. Idriss ${ }^{\# 1}$, Abdou I. Omar ${ }^{\# 2}$, Mohamed-Awal A. Mohamed ${ }^{\S 3}$, Omar A. Mohamed ${ }^{\$ 4}$, \\ Omar A. Dabar $*^{5}$ \\ \# Research Center at the University of Djibouti (CRUD/GRE), Faculty of Engineers, \\ Street Djanaleh, B.P. 1904, Djibouti \\ 1abdoulkader_ibrahim_idriss@univ.edu.dj \\ 2abdou_idriss_omar@univ.edu.dj \\ ${ }^{\S}$ Research Center at the University of Djibouti, Faculty of Sciences, \\ Street Djanaleh, B.P. 1904, Djibouti \\ ${ }^{3}$ mohamed-awal_abdillahi_mohamed@univ.edu.dj \\ \$ Direction de la Statistique et des Etudes Démographiques (DISED), \\ Immeuble Sarian, B.P.1846, Djibouti \\ ${ }^{4}$ omarabdoulkaderm@gmail.com \\ * Institute for Earth Sciences, Centre d'Etudes et de Recherche de Djibouti (CERD/GRE), \\ Airport street, BP 486, Djibouti \\ 5assowe440@gmail.com
}

\begin{abstract}
This paper presents the performance testing and promotion of solar cooking in Republic of Djibouti. Djibouti shows tremendous solar potential, therefore, solar cooking technology is as a solution to reduce energy requirements and environmental degradation. The Global Horizontal Irradiance (GHI) is 4.7-7.3 $\mathrm{kWh}$ per square meter per day $\left(\mathrm{m}^{2} /\right.$ day) throughout most of the country. The thermal performance parameters, first figure of merit $\left(F_{1}\right)$, second figure of merit $\left(F_{2}\right)$ and standard cooking power $\left(P_{\text {adj }}\right)$ suggested by Bureau of Indian Standard for solar cookers, have been evaluated by experimental studies. It is found that solar cooker is of A grade. Also comparative analysis to literature findings has been investigated to prove the thermal efficiency of proposal solar cooker. The experimental results obtained for thermal performance show that the solar cooker is capable of cooking a variety of foods easily under Djiboutian climate.
\end{abstract}

Keyword - Solar cooker, Figure of merit, Rural population, Adjusted cooking power, Thermal performance

\section{INTRODUCTION}

In the developing country, energy access is the major problem. The energy demands are increasing sharply. Due to this reason, the people around the world are switching to renewable energy sources. Over one third of the world's population still uses solid biomass for cooking, lighting, and/or heating, causing serious problems with respiratory health and deforestation [1]. In Djibouti, a large number of people live in rural areas. Wood, charcoal and kerosene are main cooking source for them which result in deforestation and environmental pollution. Fortunately, Djibouti possess ample amount of solar radiation and this offers solar cooking as one of the most attractive options.

Solar cookers have a long history dating back almost to $18^{\text {th }}$ century. According to B. Halacy and C. Halacy [2], the first experiments on solar cookers were carried out by a German Physicist named Tschirnhausen (16511708). Then the first solar furnace was fabricated by naturalist George Louis Leclere Buffon (1707-1788). But Nicholas de Saussure (1740-1799) was first in the world to use solar box for cooking. And in 1767, FrenchSwiss Physicist Horace de Saussure attempted to cook food via solar energy. He constructed a miniature greenhouse with 5 layers of glass boxes turned upside down on a black table and reported cooking fruit [3].

In this paper, we have studied and tested the solar cookers funded by Environmental Global Fund in its environmental micro-financing program.

This research integrates the project of the environmental protection framework initiated by the Ministry of Environment and Djiboutian Agency for the Social Development.

The main objective of this present work is to evaluate the thermal performance of the solar cooker under Djiboutian climate, using the standard procedure established by Bureau of Indian Standards (BIS) for testing solar cooker. The first part of this research concentrated on the climate analysis and energy consumption context in Djibouti. 
And the second part, the Figure of merits $\left(\mathrm{F}_{1}\right.$ and $\left.\mathrm{F}_{2}\right)$ and adjusted cooking powers $\left(\mathrm{P}_{\mathrm{adj}}\right)$ are calculated for the system. Finally, the readings obtained from the conducted tests have been evaluated and the results are compared to literature findings.

\section{CLIMATE ANALYSIS AND ENERGY CONSUMPTION CONTEXT IN DJIBOUTI}

Djibouti lies at the southern entrance to the Red Sea and covers a surface area of 23000 square kilometers $\left(\mathrm{km}^{2}\right)$. It has $370 \mathrm{~km}$ of maritime coastlines, and shares borders with Eritrea, Ethiopia and Somalia. The country has a semi-arid climate, mainly stony semi-desert, with scattered plateau and highlands. This makes it very sensitive to drought and water scarcity risks. It has a highly variable and low precipitation regime with an annual rainfall of 50-300 millimeters (mm). Fig. 1-(a) shows the Global Horizontal Irradiance (GHI) recorded on 2015 for Djibouti in three different weather stations, which are Camp Lemonier [4], Pillot et al. [5] and Nasa [6]. In Fig. 1-(b), the temperatures curves are high at $20-30^{\circ} \mathrm{C}$ during the cool season and $30-38^{\circ} \mathrm{C}$ during the hot season in May to September. This contributes to high levels of evaporation and transpiration equivalent to 2000 mm per year. Historical records show the Djibouti climate clearly experiences high hydrological uncertainty, frequent dry spells and chronic water stress. The GHI is 4.7-7.3 $\mathrm{kWh}$ per square meter per day $\left(\mathrm{m}^{2} /\right.$ day) throughout most of the country with little variation all the year. By comparison, Germany, which has nearly half the world's installed solar PV capacity, has few locations with a GHI above $3.5 \mathrm{kWh} / \mathrm{m}^{2} /$ day. Phoenix, Arizona a city in the US Southwest famed for its solar potential has an average GHI of $5.7 \mathrm{kWh} / \mathrm{m}^{2} / \mathrm{day}$. These features are likely to be worsened by climate change, with wide-ranging implications for the national economy, food security and human development. Given its climate and geography, Djibouti has the potential and opportunity to motivate the use and adoption of solar cookers [4], [5]. Djibouti has two peak periods of insolation (March to April and September to October) with low diurnal variation between maximum and minimum radiation values. The lowest radiation values are observed from June to August, coinciding with the hot and humid season. However, even during these periods, the country receives enough solar radiation (about $5-6 \mathrm{kWh} / \mathrm{m}^{2} / \mathrm{day}$ ) to make use of solar energy applications. According to Pillot et al. [5], about $82 \%$ of the country receives annual mean global radiation of over $2000 \mathrm{kWh} / \mathrm{m}^{2}$.
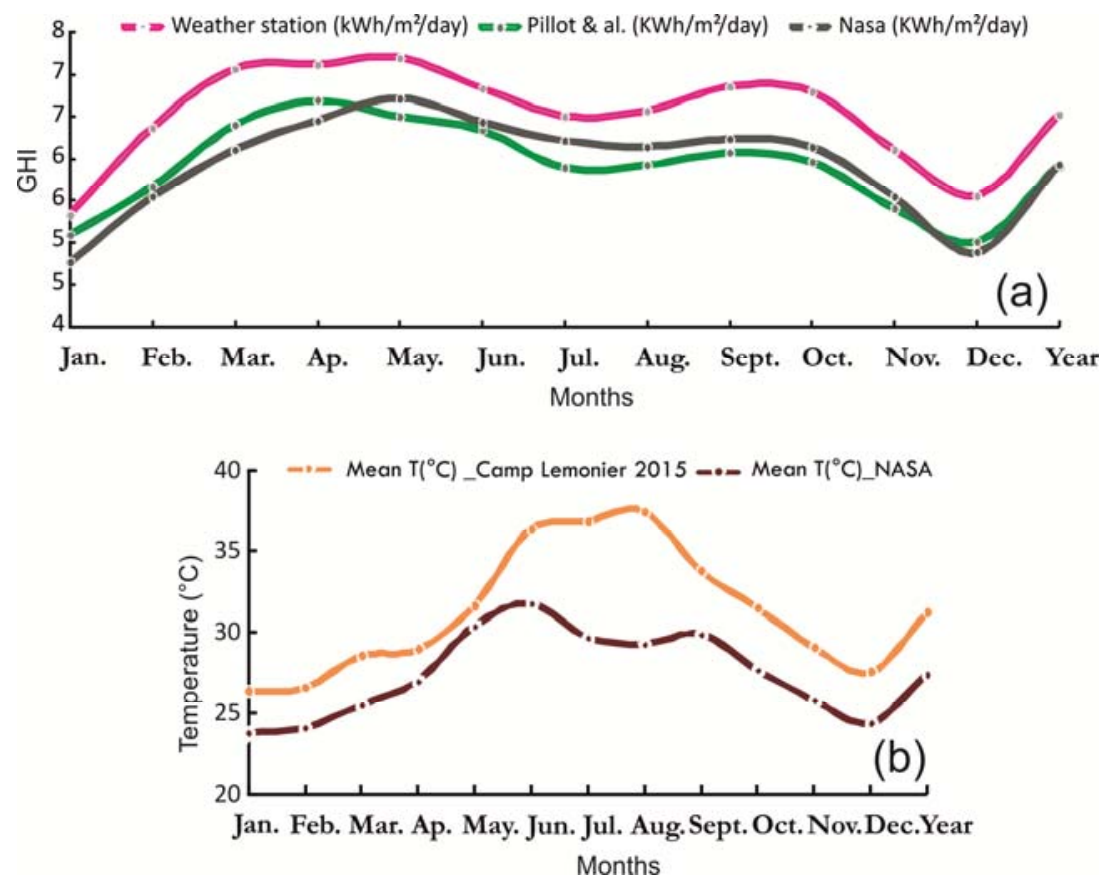

Fig. 1 Comparison of the Djibouti's monthly mean for the same coordinates (Latitude : 11.550 and Longitude : 43.150) for three weather stations (a) Global Horizontal Irradiance and (b) temperature.

In Republic of Djibouti, according to the DISED survey [7] and others calculations [8], [9] as illustrated in Table I, the households use five different methods for cooking. A number of households in peripheral and rural (districts) use wood fire for cooking (55.2\% in 2012); the survey estimated 1200 households consume 1700 $\mathrm{Kg} / \mathrm{year}$. The number of these households is declining because wood is costly and not always available, whereas kerosene is widely distributed by the government (approximately 60.6\% in Republic of Djibouti). A very few households use charcoal for cooking, because is more frequently used. The average consumption per household was estimated at $29.6 \mathrm{Kg} / \mathrm{year}$. This statistics may translate to the fact that in nearest future, sun solar energy for cooking is the best way to reduce the environment impact and to benefit the significant level of solar insolation in Djibouti. There is need to source for abundant and available alternative. Therefore, solar cookers offer a most benefits to social context particularly for peripheral and rural population in Djibouti. 
TABLE I. Different Methods for Cooking Taken by DISED Survey in 2012 [7].

\begin{tabular}{|c|c|c|c|}
\hline Different methods for cooking & Djibouti (\%) & Districts (\%) & Republic of Djibouti (\%) \\
\hline Electricity & 6.1 & 4 & 5.5 \\
\hline kerosene & 78.3 & 18 & 60.6 \\
\hline Butane Gas & 3.2 & 1.2 & 2.6 \\
\hline Wood fire & 2.1 & 55.2 & 17.6 \\
\hline Charcoal & 8.4 & 18.9 & 11.5 \\
\hline others & 1.9 & 2.7 & 2.1 \\
\hline Total & 100 & 100 & 100 \\
\hline
\end{tabular}

\section{MATERIALS AND METHODS}

This section presents the examination and study of a solar cooker, which is a device, consisting of an outer box made of aluminum sheet and inner box was also fabricated of aluminum and coated by a black paint. The paint is very important to absorb solar radiation and to transfer by conduction the heat to the cooking pots. Between the outer and inner box, an insulating material is placed (4 mm the thick) such as a double wall glass to reduce heat losses from the cooker. The plan mirror is fixed on the movable reflector over the cooker, it can be varied from $0^{\circ}$ to $115^{\circ}$ and protect the glass covers when closed. The solar cooker can be kept inside it for cooking three aluminum dishes or pots simultaneously. The pot covers was painted with flat black paint on the exterior. The dimensions of the box were $51.5 \mathrm{~cm}$ x $51.5 \mathrm{~cm}$ x $20 \mathrm{~cm}$. The diameter of the aluminum pot or dishes is 180 $\mathrm{mm}(\mathrm{R}=9 \mathrm{~cm})$ and it has a depth of $60 \mathrm{~mm}$. Fig. 2 (a) and (b) show the design of solar cooker and the cooking pot, respectively, under investigation.
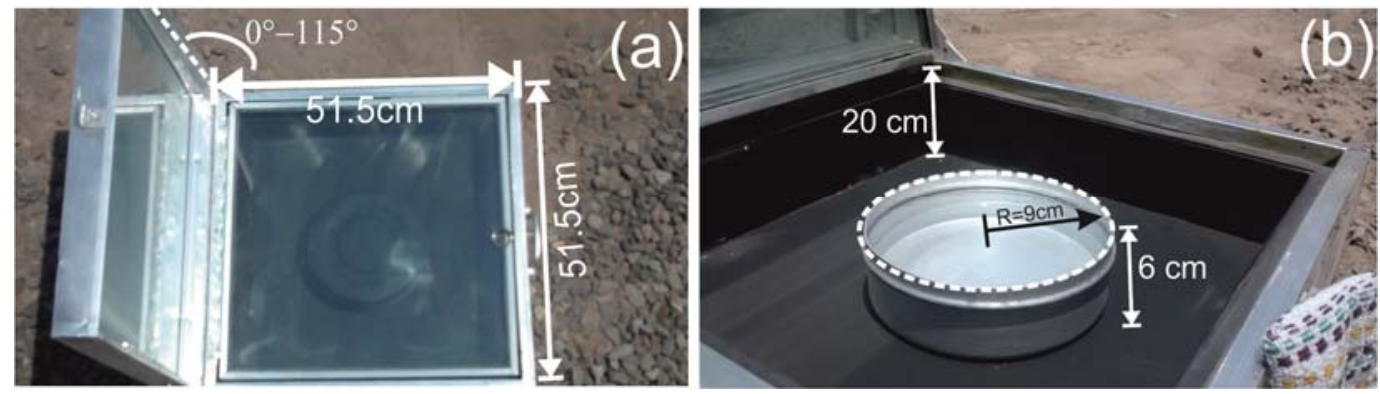

Fig.2. Designed and realized (a) solar cooker prototype and (b) the cooking pot for Djiboutian climate.

The solar cooker was exposed to the solar radiation both directly and from the reflector. And its position wasn't changed to follow the sun's movement.

A series of experiments with and without the reflectors are performed on the solar cooker under Djiboutian climate prevailing winter and summer conditions. GHI data was collected from Camp Lemonier site which is located in Djibouti at $11^{\circ} 550^{\prime} \mathrm{N}$ latitude and 43150’E longitude. In Fig. 1, the experiment was conducted during the months of March and May where solar radiation was high. Also, we can extract some tendencies from these irradiation maps. Hence, March, April and May present the highest mean values over the country, because of a sun trajectory close to zenith. Low mean solar irradiations for July and August are explained by the presence of dust in the air, due to the "khamsin" sandstorm. At last, February is the month which seems to present the highest meteorological variability with the maximum standard deviation and the minimum mean of all the set.

Fig. 3 shows the variation of the GHI per day and the experiments was conducted for two days: 03/29/2015 and 05/15/2015 with a GHI $5.2 \mathrm{kWh} / \mathrm{m}^{2} /$ day and $6.3 \mathrm{kWh} / \mathrm{m}^{2} /$ day respectively. It was observed that the profile remains high while the GHI average approaching $5.5 \mathrm{kWh} / \mathrm{m}^{2} /$ day for the both months. Moreover, it is seen that the intensity of the solar radiation is less during cloudy days (March 10, 16, 20 and 24, May 5, 8 and 28). 


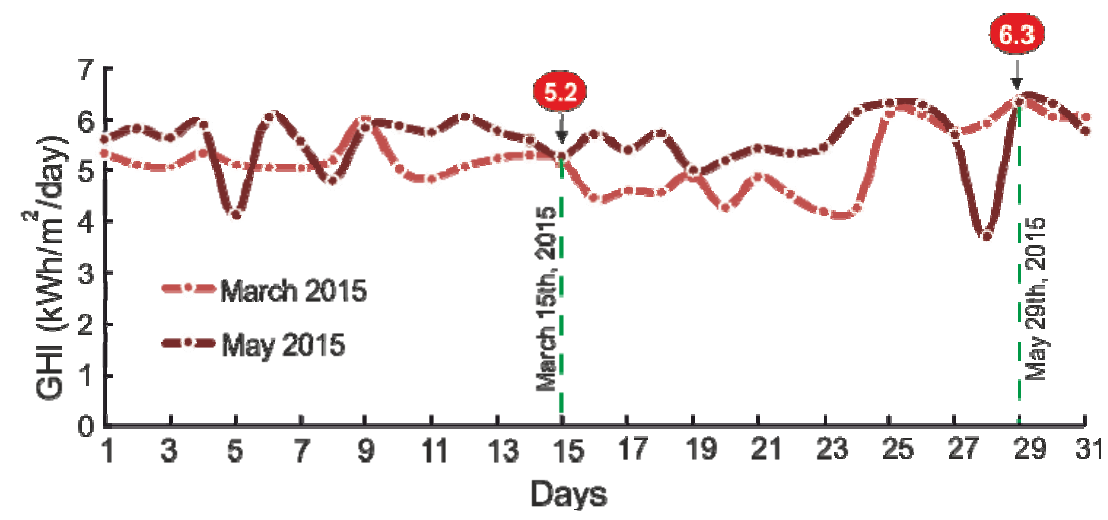

Fig. 3 Variation of the Global Horizontal Irradiance in Camp Lemonier for two months (March and May 2015).

The experiments were conducted for two days: 03/29/2015 and 05/15/2015 with a GHI $5.2 \mathrm{kWh} / \mathrm{m}^{2} /$ day and $6.3 \mathrm{kWh} / \mathrm{m}^{2} /$ day respectively.

During all experiments, the solar radiation intensity was measured by a class 2 CMP- Kipp and Zonen pyranometer type (range: $0-1000 \mathrm{~W} / \mathrm{m}^{2}$, accuracy $+/-2 \mathrm{~W} / \mathrm{m}^{2}$ ) and fixed at a horizontal position. In the case of the stagnation tests of the cooker, all the temperature measurements were carried out using K-type thermocouple coupled to digital thermometer (range : $-50^{\circ} \mathrm{C}$ to $1000^{\circ} \mathrm{C}$, accuracy $+/-0.1^{\circ} \mathrm{C}$ ). The wind speed was measured by using the PCE-TA 30 thermo-anemometer type (range wind speed: $1 \mathrm{~m} \cdot \mathrm{s}^{-1}$ to $30 \mathrm{~m} \cdot \mathrm{s}^{-1}+/-0.01 \mathrm{~m} \cdot \mathrm{s}^{-1}$, range temperature: $-10^{\circ} \mathrm{C}$ to $60^{\circ} \mathrm{C}+/-0.1^{\circ}$ ). For each measure, the temperature of absorber plate, ambient temperature $\left(\mathrm{T}_{\mathrm{a}}\right.$ ), wind speed and horizontal solar irradiation intensity (Is) were recorded at 1 minute intervals using a data logger system connected on computer. The following two tests have been performed:

- The thermal performance was calculated with the stagnation test: the solar cooker without any load and without reflector was exposed to sunlight [10]-[14].

- The sensible heat test: with water load (same mass of water at the same temperature) without reflector [15], [16].

\section{EXPERIMENTAL RESULTS AND DISCUSSION}

The three thermal performance parameters, first figure of merit $\left(\mathrm{F}_{1}\right)$, second figure of merit $\left(\mathrm{F}_{2}\right)$ and adjusted cooking power $\left(\mathrm{P}_{\mathrm{ad}}\right)$ have been calculated as per International Standard and BIS [14], [15]. The experimental time period was from 5:00 to 20:00. Simultaneously, under the real climatic conditions of Djibouti the values of solar irradiance and ambient temperatures were also measured for two working days as shown in Fig.4. The maximum solar intensity was around 12:00 and 13:00 for 05/15/2015 and 03/29/2015 respectively. Also, the variations in temperature vs. time of day are shown in the same figure. Temperatures are high at $20-30^{\circ} \mathrm{C}$ during the cool season and $30-45^{\circ} \mathrm{C}$ during the hot season in May to September. During the tests, the solar cooker without reflector and without any load was exposed to sunlight from 10:00 to 16:00 and the stagnation temperature of absorber plate was recorded in every 5 minutes interval for two different days. The high ambient temperature recorded in $05 / 15 / 2015$ was $31.9^{\circ} \mathrm{C}$ and that in $03 / 29 / 2015$ was $29.6^{\circ} \mathrm{C}$ when the solar radiation was between $750 \mathrm{~W} / \mathrm{m}^{2}$ and $878 \mathrm{~W} / \mathrm{m}^{2}$. It was observed for the two curves in Fig. 4 shows the ambient temperature decrease between 5:00 and 9:00 for the two testing days directly related to the fact that it is cooler. The wind speed at the level of glazings of solar maximum was also considered according to the BIS and for the two days, the maximum speed was $0.8 \mathrm{~m} / \mathrm{s}$ and $0.5 \mathrm{~m} / \mathrm{s}$ in average. The booster-mirror was not used during these thermal tests, as suggested by BIS.

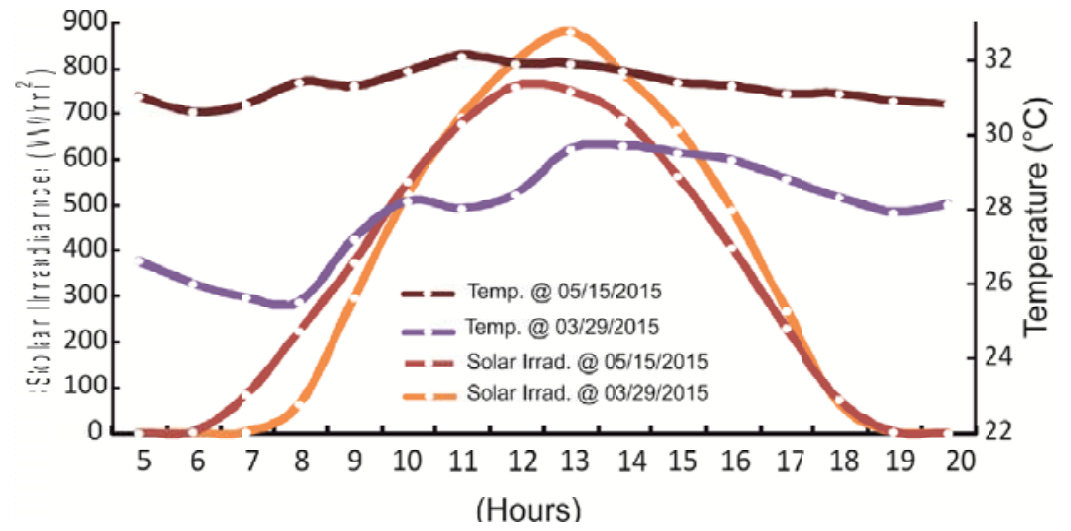

Fig. 4. Solar irradiance and temperature curves for two working days: 05/15/2015 and 03/29/2015 for thermal performance under stagnation test condition. 
Several researches were conducted on the thermal testing and performance evaluation of solar cookers [17], [18]. The value of absorber plate temperature, the ambient temperature and insolation values, which were observed during the stagnation test by the researchers for their solar cookers, are listed in the Table II. Stagnation test results for our novel solar cookers under Djiboutian climate are also included in this table.

Table II. Comparison of First Figure of Merit $\left(\mathrm{F}_{1}\right)$ of our Novel Solar Cooker with the Others Solar Cookers

\begin{tabular}{|c|c|c|c|c|c|c|}
\hline References & $\begin{array}{c}\text { Stagnation } \\
\text { temperature } \\
\left({ }^{\circ} \mathbf{C}\right)\end{array}$ & $\begin{array}{c}\text { Ambient } \\
\text { temperature: } \\
\text { Ta }\left({ }^{\circ} \mathbf{C}\right)\end{array}$ & $\begin{array}{c}\text { Time } \\
(\mathbf{I S T})\end{array}$ & $\begin{array}{c}\text { Insolation } \\
\text { value: Is } \\
\left(\mathbf{W} / \mathbf{m}^{\mathbf{}} \mathbf{)}\right.\end{array}$ & $\mathbf{F}_{\mathbf{1}}$ & $\begin{array}{c}\text { Date of } \\
\text { experiment }\end{array}$ \\
\hline $\begin{array}{c}\text { Vaishya et al. } \\
\text { (1985) [19] }\end{array}$ & 122 & 32 & $12: 00$ & 1020 & 0.088 & $\begin{array}{c}23 \text { september } \\
1982\end{array}$ \\
\hline $\begin{array}{c}\text { Negi and Purohit } \\
\text { (2005) [20] }\end{array}$ & 140 & 27 & $12: 00$ & 750 & 0.15 & march 2002 \\
\hline $\begin{array}{c}\text { Harmim et al. } \\
\text { (2013) [21] }\end{array}$ & 140 & 48 & $12: 00$ & 960 & 0.09 & 23 july 2008 \\
\hline $\begin{array}{c}\text { Mahavar et al. } \\
\text { (2012) [22] }\end{array}$ & 144 & 35 & $13: 30$ & 945 & 0.115 & 17 june 2009 \\
\hline $\begin{array}{c}\text { Our proposed } \\
\text { solar cooker }\end{array}$ & 143 & 29.6 & $13: 00$ & 878 & 0.129 & 29 march 2015 \\
\hline $\begin{array}{c}\text { Our proposed } \\
\text { solar cooker }\end{array}$ & 151 & 31.9 & $12: 00$ & 750 & 0.158 & 15 may 2015 \\
\hline
\end{tabular}

Table II reveals that stagnation temperatures for the novel solar cooker are comparable to the solar cookers proposed by the other researchers. The values of two testing days of $F_{1}$ have been calculated as per International Standard [17], [18], which is found to be 0.158 and $0.129{ }^{\circ} \mathrm{C} \mathrm{m} / \mathrm{W}$ for $05 / 15 / 2015$ and $03 / 29 / 2015$, respectively. These are the recommended values of Bureau of Indian Standards for solar cookers. The boostermirror was not used during these thermal tests, as suggested by BIS. The high stagnation temperature corresponds to the high insolation attained during the period of test. Based on Indian standards, any designed solar box cooker with $\mathrm{F}_{1}$ greater than 0.12 and above is classified as grade $\mathrm{A}$ and if otherwise, it is classified as grade $B$ [19]. The high value of first figure of merit $F_{1}$ is as a result of high optical efficiency and high insolation, as well as low convection and radiation loses from the solar cooker.

The second figure of merit of the cooker $\left(\mathrm{F}_{2}\right)$ which corresponds to heat transfer efficiency of the cooker at low heat capacity of cooker interior is calculated from sensible heat test (water heating test) of $1 \mathrm{~kg}$ of water in the cooker using International Standard. The time required to raise the temperature of $1.0 \mathrm{~kg}$ of water from $60^{\circ} \mathrm{C}$ to $90^{\circ} \mathrm{C}$ was about 40 minutes which corresponds to the second figure of merit $\left(\mathrm{F}_{2}\right)$ calculated from [11]-[15] to be 0.473 . The criteria for $F_{2}$ value by Indian standard is that $F_{2}$ should be greater than 0.42 . From Table III, the $F_{2}$ value of 0.473 obtained for our novel solar cooker compare favorably with the standard. It should be noted that $\mathrm{F}_{2}$ value to be nearly equal to the $\mathrm{F}_{2}$ values of the systems of different authors [20]-[22].

Table III. Comparison of Second Figure of Merit $\left(\mathrm{F}_{2}\right)$, Adjusted Cooking Power $\left(\mathrm{P}_{\mathrm{ad}}\right)$ and Standardized Cooking Power with the Other box Type Solar Cookers.

\begin{tabular}{|c|c|c|c|c|}
\hline References & $\mathbf{F}_{2}$ & $\begin{array}{c}\text { Water } \\
\text { load (kg) }\end{array}$ & $\mathbf{P}_{\text {ad }}$ & $\begin{array}{c}\text { Standardized } \\
\text { cooking Power (W) }\end{array}$ \\
\hline Mahavar et al. [22] & 0.466 & 1.2 & $103.5-1.474 * \Delta \mathrm{T}$ & 29.8 \\
\hline El-Sebaii and Aboul-Enein [23] & 0.407 & 4 & $103.92-1.598 * \Delta \mathrm{T}$ & 24.02 \\
\hline Harmim et al. [24] & 0.478 & 3.5 & $136.28-1.142 * \Delta \mathrm{T}$ & 78.9 \\
\hline Our proposed solar cooker & 0.473 & 1 & $110.4-1.211^{*} \Delta \mathrm{T}$ & 73.7 \\
\hline
\end{tabular}

The adjusted cooking power is calculated according to the International Standard procedure [17] and also included in this table. The adjusted cooking powers $\left(\mathrm{P}_{\mathrm{ad}}\right)$ as a function of the temperature difference $(\Delta \mathrm{T})$ for developed solar cookers can be written as follows:

$P_{a d}=110.4-1.211 \Delta T$ 
The values of regression coefficient $R^{2}=0.8978$ satisfy the test standard [17]. The value of standardized cooking powers is $73.7 \mathrm{~W}$. This value is good value as per studies as in [15], Mahavar et al. [22] and near the Harmim et al. [24] for their systems.

The loss coefficients obtained from the slope of the regression lines are observed to be $1.211 \mathrm{~W} /{ }^{\circ} \mathrm{C}$ for our novel solar cooker. The adjusted cooking power is compared with other box-type solar cookers in Table III [22]-[24].

In Djibouti, the solar energy is most available during midday and the largest meal in typically is not until evening. Thermal mass and insulation in the solar cooker, and use of slow cooking, can delay the end of cooking time until later in the day and synchronize need with availability.

Our solar cookers can made with local and inexpensive materials using simple techniques. These solar cookers will be distributed in several villages and will have long term impacts on the environment, as it will contribute to desertification and mitigating global warming.

\section{CONCLUSION}

The overall thermal performance of the solar cooker was evaluated under the Djiboutian climate. The figures of merit $\mathrm{F}_{1}$ and $\mathrm{F}_{2}$ as well as the standardized cooking power were validated using results from the literature review. The analysis of the cooking power is adjudged excellent. The use of the solar cooker, particularly for rural population, offers an economically advantageous alternative while reducing energy consumption as well as environment degradation due to deforestation. Therefore, it can play a major role in resolving Djiboutian's domestic energy problem for cooking.

\section{ACKNOWLEDGEMENTS}

This research work was financially supported by the Faculty of Engineers of the University of Djibouti. We are grateful to technicians for their assistance and for helping us to provide survey data.

\section{REFERENCES}

[1] I. Ruiz-Mercado, O. Masera, H. Zamora, K. Smith, “Adoption and sustained use of improved cookstoves,” Energy Policy, Vol. 39, pp. 7557-7566, 2011.

[2] B. Halacy, C. Halacy, “Cooking with the sun,” Lafayette, CA: Jack Howell, 1992.

[3] D.G. Fullerton, N. Bruce, S.B, Gordon, "Indoor air pollution from biomass fuel smoke is a major health concern in the developing world,” Trans. R. Soc. Trop. Med. Hyg, Vol. 102, pp. 843-851, 2008.

[4] Camp Lemonier, "Utilization of meteosat satellite radiation data for Republic of Djibouti," 2015 http://www.infoclimat.fr/observations-meteo/temps-reel/camp-lemonier/69675.html (access date: 05.15.15).

[5] B. Pillot , M. Muselli, P. Poggi , J.B. Dias, "Satellite-based assessment and in situ validation of solar irradiation maps in the Republic of Djibouti,” Solar Energy, Vol 120, pp. 603-619, 2015.

[6] NASA, "Surface meteorology and solar energy release 6.0. 2013,” https://eosweb.larc.nasa.gov/sse/ (access date: 03.29.15).

[7] Survey EDAM-IS “Direction de la Statistique et des Etudes démographiques,” Djibouti, 2012.

[8] IRENA (International Renewable Energy Agency), Renewables readiness assesment Djibouti, 2012.

[9] Annuaire Statistique. “Direction de la Statistique et des Etudes démographiques ,”Djibouti, 2015.

[10] R. Akinoso, A.k. Aremu, "Potential use of box type solar cooker in developing countries," The Journal of the Association of Professional Engineers of Trinidad and Tobago, vol. 41, pp. 11-17, 2013.

[11] BIS, "Indian standards IS 13429: solar cooker - box type”, first revision Manak Bhawan, New Delhi: Bureau of Indian Standards (BIS), 2000.

[12] S.C. Mullick, T.C. Kandpal, A.K. Sexena, “Thermal test procedure for box type solar cooker,” Solar Energy, Vol. 39, pp 353-360, 1987.

[13] O.V. Ekechukwu, N.T. Ugwuoke, “Design and measure performance of a plane reflector augmented box-type solar energy cooker”, Renewable Energy, Vol. 28, pp. 1935-1952, 2003.

[14] S.C. Mullick, T.C. Kandpal, S. Kumar, "Testing of box-type solar cooker: second figure of merit $F_{2}$ and its variation with load and number of pots," Solar Energy, Vol.57, pp. 409-413, 1996.

[15] S.D. Sharma, D. Buddhi, R.L. Sawhney, A. Sharma, "Design, development and performance evaluation of a latent heat storage unit for evening cooking in a solar cooker,” Energy Conversion and Management, Vol. 41, pp. 497-508, 2000.

[16] H.P Garg, K.P. Thanvi, “Studies on solar steam cooker”, Indian Farming, vol. 27,issue 1, pp. 29-30, 1977.

[17] P.A. Funk, "Evaluating the international standard procedures for testing solar cookers and reporting performance”, Solar Energy, Vol. 68, pp. 1-7, 2000.

[18] H. Tabor, “A solar cooker for developing countries,” Solar Energy, Vol. 10, pp. 153-157, 1966.

[19] J.S. Vaishya, T.C. Tripathi, D. Singh, B.H. Bhawalkar, M.S. Hegde, "A hot box solar cooker: performance analysis and testing,” Energy Conversion and Management, Vol. 25, pp. 373-379, 1985.

[20] B.S. Negi, I. Purohit, "Experimental investigation of a box type solar cooker employing a non-tracking concentrator," Energy Conversion and Management, Vol. 46, pp. 577-604, 2005.

[21] A. Harmim, M. Merzouk, M. Boukar, M. Amar, "Design and experimental testing of an innovative building-integrated box type solar cooker," Solar Energy, Vol. 98, pp. 422-433, 2013.

[22] S. Mahavar, N. Sengar, P. Rajawat, M. Verma, P. Dashora, "Design development and performance studies of a novel single family solar cooker,” Renewable Energy, Vol. 47, pp. 67-76, 2012.

[23] A.A. El-Sebaii, S. Aboul-Enein, “A box-type solar cooker with one-step outer reflector”, Energy, Vol. 22, pp 515-524, 1997.

[24] A. Harmim, M. Merzouk, M. Boukar, M. Amar, "cooking development in Algerian Sahara: Towards a socially suitable solar cooker,” Renewable and Sustainable Energy Reviews, Vol. 37, pp. 207-214, 2014. 


\section{AUTHOR PROFILE}

Abdoulkader Ibrahim Idriss received his Ph.D degree from the Department of Nano-Optics at the University of Franche-Comté (France) in 2010. Dr. Abdoulkader is working as an Assistant Professor in Physics at the Faculty of Engineers at the University of Djibouti since 2010, where he is currently the Dean of the Faculty of Engineers. He has supervised six Ph.D students and co-authored more than 41 papers in international journals and conferences. His research interests in the fields of nano-photonic devices, finite element method and material absorption for solar energy domain.

Abdou Idris Omar is a Fluid Mechanics and Energetics engineer. He obtained his engineering's degree from Department of Mechanics-Energetics of the ENSIAME, one of the European "Grandes écoles" of Engineering located in the city of Valenciennes in the north of France. He is currently a research scholar and a lecturer in Fluid Mechanics and Hydraulics in the Department of Energy system of the Faculty of Engineers at the University of Djibouti, Djibouti. His main areas of research interest are Energy efficiency in buildings, energy design, Thermal comfort, Bioclimatic Design, Applications of Computational Fluid Dynamics. 